\title{
Review
}

\section{Catching capital: The ethics of tax competition}

\author{
Peter Dietsch \\ Oxford University Press, New York, 2015, x+264 pp., ISBN: 978-0190251512
}

Contemporary Political Theory (2017) 16, 282-285. doi:10.1057/cpt.2016.16; advance online publication 19 April 2016

In today's globalised economy, characterised by high capital mobility but largely domestic tax policy, individuals and corporations can pick and choose between different tax regimes. In Catching Capital: The Ethics of Tax Competition, Peter Dietsch offers a commanding analysis covering the moral assessment and an institutional solution to the problem of tax competition. This book will prove useful to political philosophers and legal theorists seeking a thorough approach to global justice that proceeds from real-world practice. And, more importantly, it will also assist policymakers, lawyers and economists from fiscal policy sectors looking for a proposal that binds together the interdisciplinary theory and practice of tax competition.

Catching Capital integrates international fiscal policy and political philosophy in a readable and accessible narrative. We are offered an insightful characterisation of a moral problem - empirically, that states design their fiscal policies to attract, or 'catch', foreign capital - and an account of an institutional response thereto normatively, the design of the international fiscal regime so that states can effectively 'catch' their own capital. The choice to relegate references to abstruse philosophical and technical debates to footnotes paid off since the book's argument flows clearly, while the connections to these debates remain easy to be found.

The pivotal tension exposed in the book concerns autonomy: if international coordination is required to tackle tax competition, will states' self-determination be undermined? The book's first tour de force is to tie the case for regulating tax competition to the idea of autonomy. The objective is to determine the boundaries of national fiscal autonomy and the kinds of institutions that are capable of protecting them (p. 79). Tax competition raises a moral problem precisely because it weakens states' fiscal self-determination (Chapter 1). The two fiscal prerogatives of the state (p. 35) - setting public spending and redistribution - are put in jeopardy. By distinguishing between three main forms of tax competition - in relation to portfolio capital, paper profits and foreign direct investments (FDI) - Dietsch exposes two routes via which these two fiscal prerogatives can be brought into question. These two routes are 'poaching' (when the capital owner does not follow the

(c) 2016 Macmillan Publishers Ltd. 1470-8914 Contemporary Political Theory Vol. 16, 2, 282-285 www.palgrave.com/journals 
investment) and 'luring' (when countries attract FDI by making investments part of their tax base). What is observed is that, if countries wish to prevent important revenue losses, they have to adopt regressive fiscal policies, notably by shifting the tax burden from capital to labour, and from taxation on revenue to indirect taxation of consumption (pp. 47-48).

A second moral problem is that tax competition widens the income gap, domestically between capital owners and the rest of the population, and globally between rich and poor nations. Many developing nations lack the capacity to increase revenues by broadening their tax bases, and end up relying even more on regressive indirect taxes. This impairs these governments' abilities to fight poverty (p. 48). Moreover, the domestic inequalities created are exacerbated by increased offshore capital flight. For example, 50 per cent of the wealth of Latin American countries and up to 70 per cent of the wealth of Middle Eastern countries is held in tax havens (p. 3).

In response to the three different kinds of tax competition, Dietsch derives the principles that should regulate them: the membership principle and the fiscal policy constraint (Chapter 2, p. 80). Targeting competition for portfolio capital and paper profits, the membership principle requires that natural and legal persons pay taxes in the countries in which they benefit from infrastructure. This correctly underlines that what is under scrutiny here is not how agents spend their money, but how they receive it (p. 90), recalling the point that profits are not generated by capital alone. The membership principle comes with a demand for transparency, such that individuals and corporations make their income available for tax authorities. Yet, eliminating the competition for capital would increase the competition for real investments. This is what the second principle aims to address in the field of FDI. The fiscal policy constraint prohibits tax policies that are both unjust and strategically motivated. The implementation of these principles falls under the proposal for establishing an International Tax Organisation (ITO), which would monitor compliance and transparency, and provide a forum for settling disputes (pp. 104-112).

The question of sovereignty is further developed later in the book (Chapter 4). The chapter asks what aspects of sovereignty would have to be sacrificed under the proposed schemes of tax cooperation. It begins by exposing the tension between domestic sovereignty and the international principle of non-intervention. Whereas states maintain de jure control over their tax rates, they loose their de facto capacity to exercise their autonomy. States are indeed more interdependent today than ever before (p. 170), which imposes moral burdens on governments with regards to their fiscal policies. Here appears the book's second tour de force: replacing the obsolete idea of sovereignty as non-intervention by 'sovereignty as responsibility' (p. 175). So understood, we see that the tension between sovereignty and tax cooperation unwinds: 'these constraints are not to be viewed as constraints on sovereignty but, rather, as constraints of sovereignty' (p. 178). The book delivers on its promise to provide an account that brings the flow of capital back to the control of democratic decision making. Dietsch targets a problem in a way that will effectively reduce 
inequalities and empower states, without pretending to have a solution to solve global inequality and poverty.

An objective of the book is to provide normative underpinnings to design international regulation of tax competition. But another of the book's chief achievements consists in providing a powerful example of how political philosophy contributes to tackling a real-world injustice. One of the reasons for its success in doing so is its particular attention to questions of efficiency, feasibility, transition and incentives.

For instance, in order to understand incentive mechanisms (Chapters 1 and 5), Dietsch paints a useful portrait of the winners and losers of tax competition. He does it by looking both at the theoretical predictions and the empirical observations that balance the tax rate effect (lowering tax rates and decreasing revenues) and the tax base effect (lowering tax rates, broadening the tax base and increasing revenues) (pp. 54-62). From this, the book demonstrates how large low-income countries suffer from tax competition as their two autonomy prerogatives are violated. In contrast, large high-income countries tend to compensate for the loss of revenue by regressive measures. Their biggest losses are measured in terms of increasing inequality. By contrast, small high-income countries are big winners from tax competition.

Another central contribution to the book concerns its methodology. We observe a concern for feasibility in Dietsch's refusal to abstract from real-world considerations, which leads him to move away from redistributive approaches to political philosophy. First, he takes the division of the world into states as given, precisely in order to determine what the nature of global interactions has to tell us about the compliance of agents. Second, he acknowledges the feasibility challenges of redistributive approaches, and claims the ITO should not be regarded as a tool for redistribution. Third, he does not argue for the harmonisation of tax rates as a simple solution, for he anticipates its potential negative implications, notably its impingement on states' sovereignty. Indeed, instead arguing for a simple response, space is made in the book for quite meticulous reviews of ongoing initiatives to tackle tax competition, such as those undertaken by the OECD (for example, pp. 70-77, 112-118), all of which strengthen the case for the institutional proposal of Catching Capital.

Two points in the book remain unclear, however. Dietsch argues that, if the international tax system was just, rich and poor countries alike would have to comply with regulations (pp. 201-209). On the one hand, he points out that given that the actual system is not just, it is hard to require compliance from poor countries that benefit financially from tax competition. This discussion takes place in the chapter about transition (Chapter 5). On the other hand, earlier in the book, Dietsch also points out that as long as there is one tax haven left, there will be capital outflows from cooperating countries (p. 57). It is thus unclear how to deal with poor countries competing for foreign capital. Whether capital controls or demands for compensation would create a sufficient deterrent to prevent capital outflows remains to be proven. 
Second, the situation of developing countries deserves more attention as it relates to the proposed institutional framework. Given the centrality of the notion of autonomy in the book, surprisingly little is said about how to institutionally empower poor and developing countries. This is addressed rather quickly (p. 214). For instance, the provision of technical assistance was primarily presented as a compensatory duty (p. 214). This seems problematic to me, as these nations require technical assistance to implement adequate taxation policies, with appropriate legislation, senior officials and rigorous accountability standards, among other things. It is precisely a question of autonomy and should have been presented as part of the institutional architecture of the solution at the very beginning. Overall, however, Catching Capital is an excellent book that will become a key reference in the international fiscal policy and in the global justice scholarship.

\author{
Alexandre Gajevic Sayegh \\ University College London, London WC1E 6BT, UK \\ a.sayegh.12@ucl.ac.uk
}

